\title{
ASSESSING THE MANAGEMENT OF INSTRUCTIONAL PROGRAMMES IN SOUTH-SOUTH NIGERIAN STATE UNIVERSITIES
}

\author{
Michael Jesuarho Okagbare \\ Benson Idahosa University, Benin City, Nigeria
}

\begin{abstract}
The main aim of this research was to assess the management of Instructional Programmes in State universities in South-South Nigeria. The research employed a descriptive survey research design. One research question and one null hypothesis guided the research. The population consisted of 13,741 academic and senior administrative staff from 6 State Universities in South-South Nigeria. The Multi-stage sampling procedure was used to determine the sample size. In the second stage sampling, Proportionate Stratified Sampling Technique was used with each University serving as a stratum to obtain the number of staff members that is proportionate, which resulted in the sample size of 389 respondents. The instrument for data collection was a structured questionnaire designed by the researcher. Cronbach Alpha statistic was used to determine the internal consistency of the items. The result of the research, among others, showed both academic and administrative staff perceived that State Universities manage their staff personnel to a high extent or relatively well and that there was a significant difference between the mean rating scores of academic and administrative staff on the extent to which staff personnel are managed in State universities of South-South Nigeria. Academic and administrative staff perceived that financial resources were managed in State universities in South-South Nigeria relatively well. This means that the relative difficulties perceived to have been encountered by the products of State Universities in South-South Nigeria are either environmental or a result of other variables or dynamics that require deciphering for further research. The result showed that State governments, university managements, parents, scholarship boards, etcetera may confidently send their wards to State universities of South-South Nigeria also called the Niger Delta, for inculcation of university goals. The Study recommended among others that governments, and managements of State universities should increase grants (capital and recurrent) to universities, as this would help the universities to acquire facilities that would ensure the attainment of the universities mandate and vision.
\end{abstract}

Keywords: academic staff, management of instructional programmes, senior administrative staff, state universities.

\section{Introduction}

Instructional programmes have to do with what the school administrator does to promote teaching and learning in educational institutions. Anumber of authors have stipulated that the management of instructional programmes involves the planning and organizing, promotion, evaluation and supervision of instructions in academic institutions (Enyi, 2004a \& b; Mgbodile, 2001, 2004; Oboegulem, 2004; Oboegulem \& Onwurah, 2007; Ogbonnaya, 2003, 2009; Ogbonnaya \& Oboegbulem, 2007). This responsibility involves Heads of Departments and Deans of Faculties in universities. They are responsible for assigning courses to lecturers based on specialization and also ensuring that these courses are taught 
and examined. The Nigerian universities, whether Federal, State, or Private are managed by Governing Councils, the Vice Chancellors and other Principal Officers including the staff of the Registry Department. The Vice Chancellors constitute committees to assist them in the task of administration. They ensure, among other factors, that instructional programmes are well managed to ensure accountability.

Despite the roles and actions of these Vice Chancellors to ensure efficient management of their institutions, there are evidences of problems in the management of State universities in the South-South States of Nigeria. For example, the Amnesty Office which had sponsored large numbers of candidates to State Universities in South-South Nigeria has complained about the unwholesome behaviour and character of some of the graduates of these universities. In addition, both academic and senior administrative staff of State Universities in South-South Nigeria have indicted their University Managements for the perennial problems of delays in the payment of staff salaries and allowances; in addition the Academic Staff Union of Universities (ASUU) of Cross River State University, Calabar, and Kuku (2012) had lamented over inadequate educational facilities at the Rivers State University of Science and Technology. These issues raised a number of doubts which bother on the survival of the university system, and questions like: What is the state of the management of instructional programmes among others, in State universities in SouthSouth Nigeria? The research would put to rest the worry regarding the capacity of these State universities to produce the required university deliverables and objectives for the establishment of universities in the region. These doubts and questions among others have been cleared and answered through the assessment of the management of instructional programmes in State universities in South-South Nigeria. The main purpose of the research therefore was to assess the management of instructional programmes in State universities in South-South Nigeria. Specifically, the research sought to: determine the extent to which State universities in south-south Nigeria manage their instructional programmes. Based on this main purpose, the following question requires assessment in this research. To what extent do State universities in South-South Nigeria manage their financial resources?

\section{Research Methodology}

\section{General Characteristics}

This research adopted a descriptive survey design to assess the Management of Instructional Programmes in State universities in South-South States of Nigeria. A survey research design aimed at describing the characteristics of a given population (Fraenkel \&Wallen, 2000; Mertler \& Charles, 2008). It is sometimes referred to as a quantitative research technique in which the researcher administers some sort of survey or questionnaire to a sample or, in some cases, to the entire populations of individuals to describe their attitudes, opinions, behaviours, experiences, or other characteristics of the population (Creswell, 2005; Fraenkel \& Wallen, 2006). In surveys, views, facts among others are collated, analysed and used for answering research questions. The survey design is considered most suitable for the study because it permits the collection of first hand data from the respondents themselves, describes the present conditions as they exist in their natural and community settings, and allows that only a representative sample of the population is used for the Study. 


\section{Sample Selection}

The population of the research was all the academic and senior administrative staff of the six State universities. Statistics from the National Universities Commission show that there were six State universities in the zone, and 13,741 staff personnel in these universities (National Universities Commission 2009/2010). The sample size consisted of 389 respondents (234 academic staff and 155 senior administrative staff). The sample size was determined using the Taro Yamane's formula as cited in Edokpolor (2018). Multi-stage sampling procedure was used in determining the sample size. In the first stage sampling, simple random sampling technique by slip of papers method was used. The name of each university was written on a piece of paper and folded. The folded papers were put into a bag and shuffled thoroughly. The researcher dipped his hand into the bag and picked a piece of paper. The paper was unfolded and the name of the university it contained recorded. This process was repeated until the four universities (Akwa-Ibom State University, Delta State University, Ambrose Alli University and Rivers State University) were drawn. This was done without replacement. The use of simple random sampling technique was to ensure that all the universities have equal chance of being drawn for the research.

\section{Instrument and Procedure}

The instrument for Data Collection was a questionnaire, titled: Assessment of State Universities Management Questionnaire [ASUMQ]. The questionnaire consisted of two sections: A and B. Section "A" focused on the demographic data of respondents. Section ' $\mathrm{B}$ ' contained items built into five clusters, $\mathrm{ABCD}$ and E. A 4-point Likert type scale was provided for the respondents to indicate the strength of their opinions as follows: Very Large Extent [VLE] 4 points; Large Extent [LE] 3 points; Little Extent [LOE] 2 points; and Very Little Extent [VLE] 1 point. The instrument was subjected to face content validation by three experts, two in Educational Administration and Planning and one from Measurement and Evaluation, all in the Faculty of Education, University of Nigeria, Nsukka. The experts were requested to add or remove any item of the Instrument that they considered not useful to the research. These corrections were noted and were affected in producing the final version of the instrument which was used. To determine the internal consistency of the instrument, trial testing was carried out at Ondo State (Adekunle Ajasin University), a State university with similar characteristics, but located in a different zone in Nigeria). The choice was because they have almost the same type of management system with the State Universities being researched. Cronbach Alpha statistics was used to determine the internal consistency of the items. Reliability indices of $0.70 ; 0.63 ; 0.84 ; 0.94$ and 0.95 were obtained for each of the five clusters [A-E] respectively. The researcher had employed five research assistants who were briefed on the filling of the research questionnaire. The researcher had contacted the Registrars of State universities to which the research assistants were sent. Being a Registrar himself, the researcher had elicited the cooperation of fellow Registrars to ensure that copies of the questionnaires were effectively administered by these research assistants. 


\section{Data Analysis}

The data collected by administering the research instrument were analysed in line with the research question raised and null hypothesis formulated for the research. Descriptive statistics of mean and standard deviation were used in answering the research questions; while t-test statistics was employed to test the hypotheses at .05 level of significance.

\section{Research Results}

Table 1. Mean ratings of academic and administrative staff on the extent to which State universities manage their instructional programmes in the South-South Nigeria.

\begin{tabular}{|c|c|c|c|c|c|c|c|}
\hline \multirow[b]{2}{*}{$\mathbf{S} / \mathbf{N}$} & \multirow[b]{2}{*}{$\begin{array}{l}\text { Item Statements } \\
\text { To what extent does: }\end{array}$} & \multicolumn{3}{|c|}{$\begin{array}{c}\text { Academic } \\
N=\mathbf{2 3 4}\end{array}$} & \multicolumn{3}{|c|}{$\begin{array}{l}\text { Senior Admin } \\
\quad N=155\end{array}$} \\
\hline & & 1 & $S D_{1}$ & Remark $_{1}$ & 2 & $S D_{2}$ & Remark $_{2}$ \\
\hline 1 & $\begin{array}{l}\text { All programs in the university are fully } \\
\text { accredited by the National Universities } \\
\text { Commission. }\end{array}$ & 2.57 & 0.63 & $\mathrm{HE}$ & 2.30 & 0.65 & LE \\
\hline 2 & $\begin{array}{l}\text { Your university has the required staff mix } \\
\text { in terms of professors, readers, senior } \\
\text { lecturers, lecturer I and II }\end{array}$ & 2.65 & 0.69 & $\mathrm{HE}$ & 3.10 & 0.83 & $\mathrm{HE}$ \\
\hline 3 & $\begin{array}{l}\text { There are adequate classrooms for lectures } \\
\text { in your university. }\end{array}$ & 2.44 & 0.73 & LE & 3.05 & 0.94 & $\mathrm{HE}$ \\
\hline 4 & $\begin{array}{l}\text { Science laboratories and equipment are } \\
\text { effectively made use of by students and } \\
\text { lecturers. }\end{array}$ & 2.38 & 0.61 & LE & 2.48 & 0.55 & LE \\
\hline 5 & $\begin{array}{l}\text { Examination misconduct is firmly dealt } \\
\text { with in the university. }\end{array}$ & 2.64 & 0.68 & $\mathrm{HE}$ & 3.23 & 0.77 & $\mathrm{HE}$ \\
\hline 6 & $\begin{array}{l}\text { Semester results are released in time by } \\
\text { departments. }\end{array}$ & 2.53 & 0.68 & $\mathrm{HE}$ & 3.05 & 0.89 & $\mathrm{HE}$ \\
\hline 7 & $\begin{array}{l}\text { Lecturers always attend and teach their } \\
\text { courses as specified by the timetable. }\end{array}$ & 2.43 & 0.70 & LE & 3.23 & 0.82 & HE \\
\hline 8 & $\begin{array}{l}\text { Most students are usually present to take } \\
\text { lectures at specified times. }\end{array}$ & 2.42 & 0.72 & LE & 3.02 & 0.90 & $\mathrm{HE}$ \\
\hline & Cluster Mean & 2.51 & 0.44 & HE & 2.93 & 0.39 & HE \\
\hline
\end{tabular}

Key: $N=$ Number of respondents, $=$ Mean for academic staff, $\mathrm{SD}_{1}=$ Standard Deviation for academic staff, ${ }_{2}=$ Mean for administrative staff, $\mathrm{SD}_{2}=$ Standard Deviation for administrative staff, $\mathrm{H}=$ High extent, $\mathrm{L}=$ little extent 
Result on Table 1 shows the mean ratings of academic and administrative staff on the extent to which State universities in South-South Nigeria manage their instructional programmes. The result indicated that the academic staff had mean ratings within the range of $2.50-3.49$ set as criterion for high extent for items $39,40,43$ and 44, while mean ratings within the range of $1.50-2.49$ set as criterion for little extent were obtained for items 41 , 42,45 and 46 . The result also showed that the administrative staff had mean ratings within the range of $2.50-3.49$ set as criterion for high extent for items 40, 41 and 43-46, while mean ratings within the range of $1.50-2.49$ set as criterion for little extent were obtained for items 39 and 42 . However, a cluster mean of 2.51 with a standard deviation of 0.44 for the academic staff and 2.93 with a standard deviation of 0.39 for administrative staff were also obtained. The cluster means for both academic and administrative staff were within the range of $2.50-3.49$ set as criterion for high extent. This implies that both academic and administrative staff perceived that State universities in South-South Nigeria manage their instructional programmes to a high extent.

Hypothesis 1:

1. There is no significant difference between the mean rating scores of academic and administrative staff on the extent to which instructional programmes are managed in the state universities in South-South Nigeria.

Table 2. t-test analysis of the significant difference between the mean rating scores of academic and administrative staff on the extent to which instructional programmes are managed in the State universities in South-South Nigeria.

\begin{tabular}{|c|c|c|c|c|c|c|c|c|}
\hline $\mathbf{S} / \mathbf{N}$ & $\begin{array}{l}\text { Item Statement } \\
\text { To what extent does: }\end{array}$ & $N$ & & $S D$ & $t$ & $d f$ & $p$ & Decision \\
\hline 1 & $\begin{array}{l}\text { All programs in the university are fully } \\
\text { accredited by the National Universities } \\
\text { Commission. }\end{array}$ & $\begin{array}{l}\text { Aca } 234 \\
\text { SAd } 155\end{array}$ & $\begin{array}{l}2.57 \\
2.30\end{array}$ & $\begin{array}{l}0.63 \\
0.65\end{array}$ & 4.01 & 387 & 0.00 & $\mathrm{~S}$ \\
\hline 2 & $\begin{array}{l}\text { The university has the required staff } \\
\text { mix in terms of professors, readers, } \\
\text { senior lecturers, lecturer I and II }\end{array}$ & $\begin{array}{l}\text { Aca } 234 \\
\text { SAd } 155\end{array}$ & $\begin{array}{l}2.65 \\
3.10\end{array}$ & $\begin{array}{l}0.69 \\
0.83\end{array}$ & -5.84 & 387 & 0.00 & S \\
\hline 3 & $\begin{array}{l}\text { There are adequate classrooms for } \\
\text { lectures in my university. }\end{array}$ & $\begin{array}{l}\text { Aca } 234 \\
\text { SAd } 155\end{array}$ & $\begin{array}{l}2.44 \\
3.05\end{array}$ & $\begin{array}{l}0.73 \\
0.94\end{array}$ & -7.17 & 387 & 0.00 & S \\
\hline 4 & $\begin{array}{l}\text { Science laboratories and equipment are } \\
\text { effectively made use of by students and } \\
\text { lecturers. }\end{array}$ & $\begin{array}{l}\text { Aca } 234 \\
\text { SAd } 155\end{array}$ & $\begin{array}{l}2.38 \\
2.48\end{array}$ & $\begin{array}{l}0.61 \\
0.55\end{array}$ & -1.67 & 387 & 0.10 & NS \\
\hline 5 & $\begin{array}{l}\text { Examination misconduct is firmly } \\
\text { dealt with in the university. }\end{array}$ & $\begin{array}{l}\text { Aca } 234 \\
\text { SAd } 155\end{array}$ & $\begin{array}{l}2.64 \\
3.23\end{array}$ & $\begin{array}{l}0.68 \\
0.77\end{array}$ & -7.93 & 387 & 0.00 & $\mathrm{~S}$ \\
\hline 6 & $\begin{array}{l}\text { Semester results are released in time by } \\
\text { departments. }\end{array}$ & $\begin{array}{l}\text { Aca } 234 \\
\text { SAd } 155\end{array}$ & $\begin{array}{l}2.53 \\
3.05\end{array}$ & $\begin{array}{l}0.68 \\
0.89\end{array}$ & -6.47 & 387 & 0.00 & S \\
\hline 7 & $\begin{array}{l}\text { Lecturers always attend and teach their } \\
\text { courses as specified by the timetable. }\end{array}$ & $\begin{array}{l}\text { Aca } 234 \\
\text { SAd } 155\end{array}$ & $\begin{array}{l}2.43 \\
3.23\end{array}$ & $\begin{array}{l}0.70 \\
0.82\end{array}$ & 1.04 & 387 & 0.00 & S \\
\hline 8 & $\begin{array}{l}\text { Most students are usually present to } \\
\text { take lectures at specified times. }\end{array}$ & $\begin{array}{l}\text { Aca } 234 \\
\text { SAd } 155\end{array}$ & $\begin{array}{l}2.42 \\
3.02\end{array}$ & $\begin{array}{l}0.72 \\
0.90\end{array}$ & -7.25 & 387 & 0.00 & $\mathrm{~S}$ \\
\hline & Cluster t & $\begin{array}{l}\text { Aca } 234 \\
\text { SAd } 155\end{array}$ & $\begin{array}{l}2.51 \\
2.93\end{array}$ & $\begin{array}{l}0.44 \\
0.39\end{array}$ & -9.80 & 387 & 0.00 & $\mathbf{S}$ \\
\hline
\end{tabular}

Key: $N=$ Number of respondents, Aca $=$ Academic staff, SAd $=$ Senior Administrative staff, $=$ Mean, SD $=$ Standard Deviation, $t=\mathrm{t}$-test value calculated, $\mathrm{df}=$ degree of freedom, $p=$ percentage value calculated, $\mathrm{S}=$ Significant 
Result on Table 2 showed the $t$-test analysis of the significant difference between the Mean ratings of academic and administrative staff on the extent to which instructional programmes are managed in the State universities in South-South Nigeria. The result showed that $t$-values obtained for items 39-41 and 43-46 had associated probabilities less than 0.05 set as level of significance, which showed that there was a significant difference between the Mean ratings of academic and administrative staff on these items. Notwithstanding, a $t$-value of -1.67 obtained for item $42 \mathrm{had}$ an associated probability value of 0.10 which is greater than 0.05 set as the level of significance, and this means that there was no significant difference between the Mean rating of academic and administrative staff on the item. However, a cluster t-value of -9.80 with associated probability value of 0.00 at 387 degree of freedom was also obtained. Since the associated probability value of 0.00 for the cluster was less than 0.05 set as the level of significance, there was a significant difference between the Mean ratings of academic and administrative staff. Therefore, the null hypothesis 1 $\left(\mathrm{Ho}_{1}\right)$ which stated that there is no significant difference between the mean rating scores of academic and administrative staff on the extent to which instructional programmes are managed in the State Universities in South-South Nigeria was rejected. The conclusion drawn was that there is a significant difference between the mean rating scores of academic and administrative staff as regards the extent to which instructional programmes are managed in the State universities in South-South Nigeria.

\section{Discussion}

The findings of the research as presented on Table 1 show the mean ratings of academic and senior administrative staff on the extent to which State universities in SouthSouth Nigeria manage their instructional programmes. The result indicated that both academic and senior administrative staff perceived that State universities in South-South Nigeria manage their instructional programmes to a high extent. The findings from the test of hypothesis showed that there was a significant difference between the mean rating scores of academic and senior administrative staff on the extent to which instructional programmes are managed in State universities in South-South Nigeria. The result of the study is also consistent with Uwaifo (2009) who carried out a study on attaining standards in technology education in Nigerian universities through effective utilization of physical facilities and management of instructional programmes, and found among other things, that instructional programmes in Nigeria universities are managed to a high extent. The result of this Study therefore showed that Nigerian universities manage their instructional programmes to a high extent or relatively well.

\section{Conclusions}

The conclusion from the findings of the research clearly elucidate the fact that both academic and senior administrative staff of State universities in South-South Nigeria are in agreement more or less that these universities are properly managed in the aspect of instructional programmes. This is an important score card in the assessment of institutional accreditation; therefore, these universities can be said to be properly managed to achieve organizational objectives and goals. The statistically significant difference in the perception 
of academic and senior administrative staff notwithstanding, these universities can be said to be properly managed in this regard. The perception of these key functionaries is important for the knowledge of the internal workings of these universities. As is said in African parlance, if the fish emerges from the water and informs that the crocodile has one eye, can it be doubted? They both have been in interaction in the waters. The slight differences in the perception of academic and senior administrative staff could be likened to the plight of siblings living under one roof. Left alone to themselves, there are bound to arise bickerings, arguments and differences among them; but if they are confronted by an external aggressor, such differences would sink into unity, to confront the outsider!

\section{Implications}

From the foregoing discussion based on the findings of the study, the overall implication of these findings is that:

i. State universities in South-South Nigeria have capacity to manage State universities adequately enough to provide university deliverables and offer the required solutions to the basic socio-economic and environmental problems which bedevil the world at global, regional and local levels.

ii. Accordingly, the undesirable and untoward behaviours and characteristics which experts claim to have observed is some of the products of these universities are either inherent, environmental, or the result of other variables or dynamics which require deciphering.

iii. A fall out of the findings is that governments, university administrators, scholarship Boards, parents and other stakeholders should adequately finance State universities in South-South Nigeria.

\section{References}

Creswell, J. W. (2005). Educational research: Planning, conducting, and evaluating quantitative and qualitative research $\left(2^{\text {nd }} E d\right)$. Upper Saddle River, New Jersey: Merrill/Prentice Hall.

Edokpolor, J. E. (2018). The use of students-centred methods in the teaching of business studies in junior secondary schools. Journal of Education in Developing Areas, 26 (1), 23-31.

Enyi, D. (2004a). The administrative process. In T. O. Mgbodile (Ed.), Fundamentals in educational administration and planning (pp. 88-104). Enugu: Magnet Business Enterprise.

Enyi, D. (2004b). Theories in educational administration, In T. O. Mgbodile (Ed.), Fundamentals in educational administration and planning (pp. 69-87). Enugu: Magnet Business Enterprise.

Fraenkel, J. R., \& Wallen, N. E. (2000). How to design and evaluate research in education. (4th Ed). New York: McGraw-Hill.

Fraenkel, J. R., \& Wallen, N. E. (2006). How to design and evaluate research in education (6th Ed). Boston: McGraw-Hill.

Kuku, K. K. (2012). A brief on the presidential amnesty programme: Global agenda for development. Symposium, University of Ibadan.

Mertler, C. A., \& Charles, C. M. (2008). Introduction to educational research (6th Ed). Boston, MA: Pearson Education.

Mgbodile, T. O. (2001). Educational administration and supervision. Ibadan: Heinemann Educational Books. 
Mgbodile, T. O. (2004). Instructional leadership in school. In T.O. Mgboodile (Ed.), Fundamentals in educational administration and planning (pp. 140-150). Enugu: Magnet Business Enterprise.

Oboegbulem, A. I. (2004). Teacher stress and management. Enugu: Magnet Business Enterprise.

Oboegulem, A. I., \& Onwurah, C. U. (2007) Organization and management of education. Enugu: Magnet Business Enterprise.

Ogbonnaya, N. O., \& Oboegbulem, A. I. (2007). Social and political context of educational administration and planning. Unpublished manuscript.

Ogbonnaya, N. O. (2003). Principles and applications of educational policies in Nigeria. Nsukka: University Trust Publishers'.

Ogbonnaya, N. O. (2009). Social and political contexts of educational administration. Nsukka: Chuka Educational Publishers.

Ofeogbu, N. G. (2013). Continuing professional development programmes among university lecturers in Abia State. African Journal of Higher Education Studies and Development, 3 (2), 23-34.

Uwaifo, V. O. (2009). Technical education and its challenges in Nigeria in the 21st Century. International NGO Journal, 5 (2), 40-44.

Received 10 April 2019; accepted 18 June 2019

Michael Jesuarho Okagbare

The Registrar, Office of the Registrar, Benson Idahosa

University, Benin City, Edo State, Nigeria.

E-mail: registrar@biu.edu.ng 